\title{
A GENEALOGYCAL STUDY OF ISLAMIC EDUCATION SCIENCE AT THE FACULTY OF ILMU TARBIYAH DAN KEGURUAN UIN SUNAN KALIJAGA
}

\author{
Suyadi*; Sutrisno** \\ *Ahmad Dahlan University, Yogyakarta; **Sunan Kalijaga State \\ Islamic University (UIN) Yogyakarta, Indonesia \\ email:suyadi@fai.uad.ac.id
}

\begin{abstract}
This study traces the genealogy of Islamic education at the Faculty of Ilmu Tarbiyah dan Keguruan (FITK) Sunan Kalijaga State Islamic University Yogyakarta. The genealogycal approach used in Foucault's terminology means that the objectivity of science covers two aspects, namely the archeology of knowledge and power. Data is comprised of ideas and opinions that develop among lecturers at FITK. Data is analyized interpretatively, descriptively, and comparatively. Findings show that in the early period of its formation (1951), Islamic education science at FITK was influenced by religious teachings brought from the Middle East. But since the secularization of Islamic education in Turkey led by Fethullah Gülen (1990), the mecca of Islamic education has split into two poles; on the one side, it follows dogmatic religious teachings stemming from Middle East traditions, and on the other side, it needs to respond to the Western secular tradition. Since 2007 the dynamics of FITK has moved toward a dialectics of integrative Islamic education.

Tujuan penelitian ini adalah melacak akar genealogi integrasi keilmuan pendidikan Islam di Fakultas Ilmu Tarbiyah dan Keguruan (FITK) Universitas Islam Negeri Sunan Kalijaga. Pendekatan genealogi dalam terminologi Foucault dimaksudkan bahwa obyektivitas ilmu mencakup dua
\end{abstract}


unsur, yakni arkeologi pengetabuan dan kekuasaan. Data-data berupa ide dan gagasan yang labir dan berkembang dari para dosen FITK dianalisis secara interpretatif, deskriptif dan komparatif. Hasilpenelitian menunjuk.kan bahwa pada awal berdirinya (1951), embrio keilmuan pendidikan Islam di FITK dikuasai ilmu-ilmu agama dari Timur Tengah. Tetapi, sejak terjadi sekularisasi pendidikan Islam di Turki yang dipimpin Fetbullah Gülen (1990), kiblat keilmuan pendidikan Islam terpecah dan dikotomi; di satu sisi harus tunduk pada kebenaran ilmu-ilmu agama dari Timur Tengah tetapi di sisi lain harus merespon ilmu pendidikan sekuler dari Barat. Dalam perkembangan mutakbir, tepatnya sejak. 2007 dinamika keilmuan FITK bergerak. menuju dialektika keilmuan pendidikan Islam yang integratif]

Keywords: Genealogy of knowledge, Islamic education, Integrative, Faculty of Ilmu Tarbiyah dan Keguruan

\section{A. Introduction}

Searching the genealogycal roots of Islamic education science has become a central topic since Abdul Munir Mulkhan claimed that Islamic education does not have philosophy, science, theories, and tarbiyah technology. ${ }^{1}$ The Faculty of Tarbiyah (Fty) was initially established in 1951 and was then renamed in 2004 as the Faculty of Ilmu Tarbiyah dan Keguruan (shortened as FITK). Since then, it has developed a distinct academic profile with academic guides and manuals, but not created official documents that include Islamic education itself. Because of this, students at FITK are required to study myriad of courses, from religious teachings such as al-Qur'an, hadith, fiqh, tarikh (Islamic history) to science, such as sociology, psychology, anthropology, physics, etc., while Islamic education itself does not exist. If there were Islamic education science, then its contents are combination of religious teachings and social-humanities. According to Mulkhan, education and philosophy of education are only description of dogmas, taught as a course but is not science. ${ }^{2}$ FITK nowadays develops many methods of teaching as best practices but these are not theoretical advancements.

1 Abdul Munir Mulkhan, "Filsafat Tarbiyah Berbasis Kecerdasan Makrifat", Jurnal Pendidikan Islam, vol. 2, no. 2 (2013), p. 224.

2 Ibid. 
There has relatively been inadequate research examining scientific genealogy in education, while much research emphasizes on religious teaching-learning practices. Ismail Suardi Wekke, for example, studies Arabic from the teaching models but not from science. ${ }^{3}$ Research of Muhammad Syukri Salleh also challenges the strategy of Islamic education, although the strategy could apply for general education. ${ }^{4}$ Raihani has investigated religious teaching practices at schools in which the majority of them encounter problems in religious teaching materials to be suitable with the beliefs of students from diverse beackgrounds. ${ }^{5}$ Raihani also conducted a study on religious education practices in minority classes, proving that minority groups, both at the macro and micro levels, are being more vurnarable due to discrimination perpetuated by the majority while, at the same time, civic protection is ignored. ${ }^{6}$ The Indonesian government provides remarkable support for religious education, while Japan spend much less on teaching students moral or religious education. Uniqueness of character, state ideology, and religion may make each government, more or less, fulfills students' need. ${ }^{7}$ Indonesia as a country recognizing religion in its state's principles has to pay educators teaching moral education at school, and this is in contrast with the Japanese who adhere liberal ideology. The studies show that Islamic education is poor in developing science but is good in teaching-learning practice. Using Foucault's terminology, there is very little research on the Islamic archeology.

Funding for Japan's liberal political ideology leeds to much less funding for moral or religious education. Indonesia's political ideology

3 Ismail Suardi Wekke, "Arabic Teaching and Learning: A Model from Indonesian Muslim Minority”, Procedia - Social and Behavioral Sciences, vol. 191 (2015), pp. 286-90.

4 Muhammad Syukri Salleh, "Strategizing Islamic Education", International Journal of Education and Research, vol. 1, no. 6 (2013), pp. 1-14.

5 Raihani et al., "Delivering Islamic Studies and Teaching Diversity in Southern Thai Islamic Schools”, Al-Jami'ab: Journal of Islamic Studies, vol. 54, no. 1 (2016), p. 123.

${ }^{6}$ Raihani, "Minority Right to Attend Religious Education in Indonesia", AlJami'ab: Journal of Islamic Studies, vol. 53, no. 1 (2015), p. 1. Indonesian government issued a new education law in which one of the articles (Article 12)

7 M. Agus Nuryatno, "Comparing Religious Education in Indonesia and Japan”, Al-Jami'ah: Journal of Islamic Studies, vol. 52, no. 2 (2014), p. 435. 
of religious pluralism requires much more funding for this aspect of education. Japan's ideology has also led to much more funding for education in the sciences. Indonesia's religious pluralism until now has held Indonesia back in the development of the sciences. In order to move Indonesia forward, educators must first develop a worldview that explains the link between all the state religions and the sciences. Because Indonesia is almost $90 \%$ Muslim. It is especially important to libk Islamic education to the sciences and to scientific methods.

Research on archeology of knowledge ${ }^{8}$ in Foucault's terminologywhich is believed to have the ability to search the genealogycal root of Islamic education science-remains little. Foucault's work that was published in 1979 entitled "The Politics of Health in The Eighteenth Century" could attract the interest of Richard A. Lynch 35 years later so Lynch felt it necessary to retranslate this book. 'Irfan Ahmad in the book "Genealogy of the Islamic State: Reflections on Maududi's Political Thought and Islamism" also used the method of genealogy to study Islam and Indonesia's state politics "Genealogy of the Islamic State: reflections on Maududi's political thought and Islamism". ${ }^{10}$ The study of David Garland also employed Foucault's method in writing a contemporary history by an archeological analysis to reevaluate a phenomenon. ${ }^{11}$ Meanwhile Serhat Kologlugil used in his economics study the method of archeological knowledge of Foucoult. ${ }^{12}$ Similarly, Simon Springer's study focused on neo-liberal economy between Foucault and Marxism. ${ }^{13}$ Applying the genealogycal approach, Mahruz As'ad's study

${ }^{8}$ Michel Foucault, "The Archaeology of Knowledge":, Social Science Information, vol. 9 , no. 1 (1970), pp. 175-85.

9 Michel Foucault, "The Politics of Health in the Eighteenth Century", in Power/Knowledge: Selected Interviews and Other Writings, 1972-1977, ed. by Colin Gordon (New York: Harvester Wheatsheaf, 1980), pp. 166-82.

10 Filippo Osella and Benjamin Soares (eds.), Islam, Politics, Anthropology (Malden, Massachusetts: Wiley-Blackwell, 2010).

11 David Garland, "What is a 'History of the Present'? On Foucault's Genealogies and Their Critical Preconditions", Punishment \& Society, vol. 16, no. 4 (2014), pp. 365-84.

12 Foucault, "The Archaeology of Knowledge".

13 Simon Springer, "Neoliberalism as Discourse: between Foucauldian Political Economy and Marxian Poststructuralism”, Critical Discourse Studies, vol. 9, no. 2 (2012), 
focusing on contemporary moderate Islam found three discourses on Islam and Indonesia's foreign policy: Islam as religious identity, grassroots of moderate Islam, and moderate Islam as part of a global counterterrorism project. ${ }^{14}$ While Asfa Widiyanto used a genealogycal approach in his research, which is not directly connected with Islamic education, investigating Seyyed Hossein Nasr's (I. 1933) idea in the context of intellectual discourse in Indonesia. The result of this study shows an influence of Nasr's idea on the way both Nurcholish Madjid (1939-2005) and Komaruddin Hidayat have used the same approach. ${ }^{15}$ These studies using the genealogycal approach to some extent have dealt with the study of liberalism of economy and moderate Islam but do not specifically discuss the genealogy of Islamic education science.

Some studies have no relationship one to the other. Ismail Suardi Wekke, Raihani, and Agus Nuryatno tend to study Islamic education limited only to teaching practice. Whereas much research on genealogy which is particularly conducted by Serhat Kologlugil, Simon Springer, Mahruz As'ad, and Asfa Widiyanto does not connect with Islamic education science but with Islam in general. This research therefore tries to fill the gap in which genealogycal approach is employed to find scientific foundation of Islamic education at FITK. Looking internally at FTIK of this university and the others in Indonesia, the research appears to be a pioneer in terms of applying the genealogycal approach on research in Islamic education. However, compared to other faculties, the use of this kind of research at FITK context has been relatively tardy as, in 2007, Faculty of Syariah and Law (FSH), for instance, published a manuscript entitled Pemikiran Hukum Islam Dekan Fakultas Syariah: UIN Sunan Kalijaga (1963-2007) — in its 50th anniversary. ${ }^{16}$ The genealogycal approach in the terminology of Foucault was used to examine whether

pp. $133-47$.

14 Ahmad Rizky Mardhatillah Umar, "A Genealogy of Moderate Islam: Governmentality and Discourses of Islam in Indonesia's Foreign Policy", Studia Islamika, vol. 23, no. 3 (2016), pp. 399-433.

15 Asfa Widiyanto, “The Reception of Seyyed Hossein Nasr's Ideas within the Indonesian Intellectual Landscape”, Studia Islamika, vol. 23, no. 2 (2016), pp. 193-236.

16 Khoiruddin Nasution, Ahmad Pattiroy, and Slamet Khilmi (eds.), Dari Hasbi Ash-Shiddieqy hingga Malik. Madany: Pemikiran Hukum Islam Dekan Fakultas Syari'ah UIN Sunan Kalijaga Yogyakarta, 1963-2007 (Yogyakarta: Fakultas Syari'ah Press, 2009). 
there has Islamic education science been identified, then responded, discussed, and developed over time. If genealogycal studies are positioned as outsider and Islamic education research is placed as insider, ${ }^{17}$ then studies using the genealogycal approach to augment Islamic education at FITK are considered critical, and so the development of Islamic education at FITK will not be abistoric.

\section{B. Critical Phase of Islamic Education}

Since its formation in 1951, FITK has shown a crisis in Islamic education science as none of prominent scientist figures or ulama to emerge as those at other faculties. It seems to be different comparing its development with other faculties, such as that of the Faculty of Syariah through Hasbi As-Siddiqi, a prominent figure of contextual figh, or the Faculty of Ushuluddin with Ali Mukti as a forefather of Islamic philosophy. While at time, FITK did not have yet prominent figures establishing a solid foundation for Islamic education science. This situation also occurred at other Faculties of Tarbiyah within state Islamic universities/institutes throughout Indonesia, as in early time litle work of FITK lecturers was found.

The archeology of knowledge of FITK in early periods can be traced as it was in Profil LAIN Sunan Kalijaga Yogyakarta 1951-2004 stating that "Sunan Kalijaga State Islamic Institute for Islamic Studies including FITK, during its initial development period, applied a specific curriculum referring to Middle East education systems." 18 Azyumardi Azra asserts that Middle East higher education systems were likely to have normative approach than historical. ${ }^{19}$ Abd Rachman Assegaf states that in the early development, Islamic education in Indonesia including the teaching practices at FITK leaned to adopt the normative approach because of significant influences brought by alumni completing their education

17 Kim Knott, "Insider/Outsider Perspectives", in The Routledge Companion to the Study of Religion, ed. by John R. Hinnells (London: Routledge, 2005), p. 145.

18 M. Alfatih Suryadilaga and Fachruddin Faiz, Profil IAIN Sunan Kalijaga Yogyakarta 1951-2004 (Yogyakarta: Suka Press, 2004).

19 Azyumardi Azra, Jejak-Jejak Jaringan Kaum Muslim: Dari Australia bingga Timur Tengah (Bandung: Hikmah, 2007). 
from Middle East universities and colleges. ${ }^{20}$ According to Sutrisno, the normative approach may not contribute significantly to develop students' or lecturers' critical thinking. As a consequence, it can be understood that one of the major contributing factors of Islamic education crisis was the ignorance of using effective approaches in the teaching-learning. The employment of normative might be a factor.

The influence of Middle East education systems might be obviously marked in two aspects. First, the growing number of translation on Arabic textbooks to be used as reference with the normative approach. This is evidenced as Muchtar Yahya translating Ahmad Syalabi's Tarikh atTarbiyyah al-Islamiyah, and Syamsuddin translating the work of Fathiyah Hasan Sulaiman entitled al-Mąhab al-Tarbawi inda al-Gharali became Education System According to al-Ghazali. ${ }^{21}$ The Middle East books also became FITK's reference books, such as Tarbiyat al-Aulad fi al-Islam (child education in Islam) by Abdullah Nashekh Ulwan. Accordingly, the books emerged as recommended references of various subjects.

Besides translation, the work of FITK lecturers is typically normative as reflected in Muhammad Anis' textbook entitled Tafsir Ayat Pendidikan: Wabyu Pertama sebagai Lonceng Kemajuan Peradaban Umat Manusia, ${ }^{22}$ containing normative interpretation of the Qur'an, chapter al-Alaq, verses 1 through 5 then was revised under a new title Tafsir AyatAyat Pendidikan (Interpretation of Educational Verses), ${ }^{23}$ which provides comprehensive discussions about the Qur'an, especially particular verses related to Islamic education.

The approach also affected the curriculum structure of FITK in its early phases, religious studies at that time were dominant, covering about $41 \%$ of total courses, followed by Islamic studies and Islamic education courses at about $29 \%$ and $19 \%$ respectively. ${ }^{24}$ This approach

20 Abd Rachman Assegaf, Abd Razak Bin Zakaria, and Abdul Muhsein Sulaiman, "The Closer Bridge towards Islamic Studies in Higher Education in Malaysia and Indonesia", Creative Education, vol. 3, no. 6A (2012), pp. 986-92.

21 Suryadilaga and Faiz, Profil LAIN Sunan Kalijaga Yogyakarta 1951-2004.

22 Ahmad E. Q; Nurwadjah, Tafsir Ayat-Ayat Pendidikan: Hatiyang Selamat hingga Kisah Luqman (Bandung: Marja, 2007).

23 Muh Anis, Tafsir Ayat - Ayat Pendidikan (Yogyakarta: Mentari Pustaka, 2010).

24 Tim Penyusun, Kurikulum Fakultas Tarbiyah Institut Agama Islam Negeri (IAIN) Sunan Kalijaga (Yogyakarta: IAIN Sunan Kalijaga, 1970). 
also profoundly affected the process of education. The focus was on memorization and textual evaluation.

\section{Dichotomous Islamic Education}

Since the movement of secularization of Islamic education in Turkey led by Fethullah Gülen'25 in 1981, FITK scientific reference has moved from Middle East systems to the Western educational structure that can be clearly seen through the transformation of the curriculum organization, including the provision of syllabus and the use of textbooks. The subjects taught at FITK have no longer been dominated by religious studies, rather there are sufficient of science courses incorporated into the curriculum, such as English textbooks. ${ }^{26}$ This change gathered its momentum when it was championed by the policy of the 1980's Minister of Religious Affair, Mukti Ali. Ali sent a number of lecturers from State Institutes for Islamic Studies throughout Indonesia to Western countries to pursue their higher education. ${ }^{27}$

The shift from the use of Arabic textbooks to English ones marked the end of the critical phase in Islamic education. It was further signposted with the emergence of critical awareness to reflect on the future of Islamic education scientific foundation in 1990. The critical awareness was initiated by the Association of Islamic Education Scholar (ASPI) under chaiman, Ahmad Tafsir, who suggested the need of a special board responsible for developing Islamic education institutions, such as madrasah and Islamic public schools. FITK had been busy fulfilling scientific society's necessity (madrasah) yet ignoring its scientific responsibility, i.e., developing the quality of the scientific

25 Bayram Balci, "Between Secular Education and Islamic Philosophy: The Approach and Achievements of Fethullah Gülen's Followers in Azerbaijan":, Caucasus Survey, vol. 1, no. 1 (2013), pp. 107-16.

26 Tim Penyusun, Silabus Fakultas Tarbiyah LAIN (Jakarta: Proyek Pembinaan Perguruan Tinggi Agama Islam/IAIN di Pusat Direktorat Pembinaan Perguruan Tinggi Agama Islam, 1981).

27 Ali Munhanif, "Prof. Dr. A. Mukti Ali: Modernisasi Politik-Keagamaan Orde Baru”, in Menteri-Menteri Agama RI: Biografi Sosial-Politik, ed. by Saiful Umam and Azyumardi Azra (Jakarta: Diterbitkan atas kerjasama Indonesian-Netherlands Cooperation in Islamic Studies (INIS), Pusat Pengkajian Islam dan Masarakat (PPIM), Badan Litbang Agama, Depertemen Agama RI, 1998), p. 317. 
society. Moreover, the number of madrasah and Islamic public schools is small which definitely requires improvement of such aspects as theories, academic profiles, and management.

In response to this critical awareness, Abdul Munir Mulkhan and Sutrisno, both professors at FTIK, compiled an anthology entitiled Religiusitas Ilmu Pengetahuan dan Teknologi: Rekonstruksi Pendidikan dan Tradisi Pesantren has five chapters, "Religiositas Ilmu Pengetahuan Pascamodern", "Pemuliaan Kemanusiaan dalam Etika Intelektual Santri", "Akar Pendidikan Islam sebagai Ilmu", "Re-edukasi Etika Sarjana Tarbiyah" and "Re-tradisi Intelektualitas Pesantren." "28 These writings describe the two branches of Islamic education in that particular era; corporating religious elements in the development of science and technology; and integrating science and technology into Islamic education, particularly at the pesantren.

In contrast to Mulkhan's focus on science and technology and pesantren, Sutrisno promotes the development of creativity in Islamic education. His thesis entitled Pengembangan Kreatifitas dalam Pendidikan Islam Kontemporer: Telaah atas Pemikiran Muhammad Iqbal, republished under a new title, Pendidikan Islam dalam Konsepsi dan Realitas ${ }^{29}$ was like Ahmad Tafsir, scientific development of Mulkhan worried that Islamic education was understood mostly as a classroom teaching-learning process.

Sutrisno claims that many academics' understanding of Islamic education which limited only to classroom pedagogical methods in the classroom.

"Education is often understood as a teaching-learning process constrained by the classroom walls. This definition is not sufficient to cover the meaning of guidance which influences individuals or a community shaping, developing, and modifying ideas and behavior of an individual or groups." 30

In addressing the concern, Sutrisno attempts to applying Iqbal's

28 Ibid., pp. 165-85.

29 Sutrisno, "Pengembangan Kreatifitas dalam Pendidikan Islam Kontemporer, Telaah Atas Pemikiran Muhammad Iqbal”, in Pendidikan Islam dalam Konsepsi dan Realitas, ed. by Abd. Rachman Assegaf (Yogyakarta: Lembaga Penelitian UIN Sunan Kalijaga, 2006), p. 43.

30 Ibid., pp. 48-9. 
ideas, unifying research on creativity in education and Islamic thought, reflected in Iqbal's thoughts. Sutrisno asserts that creativity is a unique capacity of every individual to innovate and create something new, whether in the form of ideas or factual work. ${ }^{31}$ His concept of creativity was then combined with Iqbal's ide of "ijtihad". The word "ijtihad" has been understood as merely fiqh matters. Meanwhile, Sutrisno believes that the idea of Iqbal about ijtihad should be translated as the development of creativity in a contemporary Islamic education milieu in order to cope with the negative effects of industrialization. ${ }^{32}$

Iqbal's ideas on education started from his concept of khudi (ego). Each human is an integrated individual. He rejected Descartes's dichotomy between the spiritual and physical aspect of life. Iqbal affirms that no division exists between spiritual and physical aspect of one's life, which further characterizes an enlightment personality (insan kamil). Thus, the fundamental purpose of Islamic education is to generate a completely faithful character through a creative process. ${ }^{33}$

In 2004, Sutrisno conducted a study on "Problem Dikotomi Ilmu Dalam Islam: Upaya Integrasi Ilmu di UIN Sunan Kalijaga Yogyakarta" which gererated three clusters of integrative religion-science strategies: 1) Islamization of science (al-Faruqi); 2) Islam ‘scientification' (Kuntowijoyo), and 3) integration-interconnection (Amin Abdullah). This research was then published in an antology by the International Islamic University of Malaysia, "Integrating Science and Islam: A Case Study of State Islamic University Sunan Kalijaga Yogyakarta, Indonesia". ${ }^{34}$ Institutionally, FITK is less responsive to this matter and again held a Simposium Nasional ${ }^{35}$ in 1996 under a theme that was not relative with wind of transformation of IAIN to become UIN, that is Pendidikan Islam dan Tantangan Globalisasi. The proceedings of the symposium were then published in an anthology.

${ }^{31}$ Ibid., p. 47.

32 Ibid., p. 46.

33 Ibid., p. 70.

${ }^{34}$ Sutrisno, "Integrating Science and Islam: A Case Study of State Islamic University (UIN) Sunan Kalijaga, Yogyakarta, Indonesia", in Critical Issues and Reform in Muslim Higher Education, ed. by Rosnani Hashim and Mina Hattori (Kuala Lumpur: IIUM Press, 2015), pp. 178-97.

35 Imam Machali (ed.), Pendidikan Islam dan Tantangan Globalisasi (Yogyakarta: Presma dan Ar-Ruzz Media, 2004). 
Shortly after, FITK held a national symposium on 'Pendidikan Islam dan Tantangan Globalisasi". Two faculty members Abdul Munir Mulkhan and Abd Rahman Assegaf presented their papers and got published. ${ }^{36}$ Meanwhile Sutrisno responded the issue of globalization in his article entitled "Mengingat Kembali Jiwa Pendidikan Sebagai Respon Terhadap Globalisasi" 37 in 2010.

Many lecturers were worried about the changing vision of FITK, Abdul Munir Mulkhan, the prominent professor, publicly delivered a number of responses, one of which was the inaugural speech of his professorship, 'Kecerdasan Ma'rifat dan Revolusi Spiritual dalam Tradisi Sufi (Part One)". ${ }^{38}$ In light of hermeneutical theory, the ma'rifah quotient (MaQ) proposed by Mulkhan seems to be criticizing Daniel Goleman's Emotional Quotient (EQ) ${ }^{39}$ and Danah Zohar's Spiritual Quotient (SQ) ${ }^{40}$ Zohar's work is now becoming a trending topic worldwide. Mulkhan states that Zohar's God spot theory addresses the area of divinity, namely ma'rifat. ${ }^{41}$ At that time, the popularity of EQ and SQ motivated FITK's lecturers to do further research on these theories, for example, Karwadi's dissertation was on Kecerdasan Emosional Hasan Langgulung. ${ }^{42}$ Therefore, it

36 Abdul Munir Mulkhan, "Kesalahen Multikultural dalam Pendidikan Islam”, in Pendidikan Islam dan Tantangan Globalisasi, ed. by Imam Machali (Yogyakarta: Presma dan Ar-Ruzz Media, 2004).

37 Sutrisno, "Mengingat Kembali Jiwa Pendidikan Sebagai Respon Terhadap Globalisasi”, in Antologi Pendidikan Islam, ed. by Nizar Ali and Sumedi (Yogyakarta: Program Studi Pendidikan Islam Program Pascasarjana UIN Sunan Kalijaga dan Idea Press, 2010), pp. 131-42.

38 Abdul Munir Mulkhan, "Kecerdasan Ma'rifat dan Revolusi Spiritual dalam Tradisi Sufi”, Jurnal Pendidikan Islam, vol. 2, no. 1 (2004).

39 Daniel Goleman, Kecerdasan Emosional, trans. by T. Hermaya (Jakarta: Gramedia Pustaka Utama, 2006).

40 Danah Zohar and Ian Marshall, SQ: Memanfaatkan Kecerdasan Spiritual Dalam Berpikir Integralistik dan Holistik untuk Memaknai Kehidupan, trans. by Rahmani Astuti, Ahmad Nadjib Burhani, and Ahmad Baiquni (Bandung: Mizan, 2001).

41 Abdul Munir Mulkhan, "Tarbiyah Sebagai Ilmu dan Dasar Keilmuan Pendidikan Islam", in Antologi Kependidikan Islam (Yogyakarta: Jurusan Kependidikan Islam Fakultas Tarbiyah dan Keguruan UIN Sunan Kalijaga, 2010), p. 22.

42 Karwadi, "Emotional Quotient in Islamic Educational Perspective (A Study on Elements of Emotional Quotient Hasan Langgulung's Perspective)”, Ph.D. Dissertation (Yogyakarta: Sunan Kalijaga State Islamic University, 2008). 
is obvious that Mulkhan criticized EQ and SQ then subsequently offered $\mathrm{MaQ}$, while Karwadi studied EQ within the Islamic perspective of Hasan Langgulung. Mulkhan then reconstructed the philosophy of Tarbiyah based on ma'rifah quotient (MaQ), by including involving sufism in the academic educational paradigm. He described sufism as a unique creative process of creativity in every aspect of education, whereas Karwadi studied EQ through the perspective of Langgulung, and Rahman tried to implement EQ without research.

Mulkhan's idea, however, did not become popular even among faculty members at UIN Sunan Kalijaga. In 2006, Sutrisno wrote his dissertation investigating Fazlur Rahman's ideas about critical thinking, but was not interested in Mulkhan's suggestion to examine Rahman's thought on creativity. ${ }^{43}$ The objects of these two studies were different. Sutrisno's dissertation was essentially augmenting his master's thesis focusing on creativity in Islamic education, argues that the decline of Muslim society was not caused by the absence of MaQ, instead, it was caused by poor critical thinking as a result of philosophy and science to be failing to include in the curriculum. Islamic education therefore should be able to generate scholars who embrace critical thinking, creativity, innovation, progress, justice, honesty, and other virtuous characters. Unfortunately, for the most part, Islamic education has been implemented in a mechanical way ever since the Middle Ages of Islam.

Sutrisno's Pendidikan Islam yang Menghidupkan: Telaah terhadap Pemikiran Fąlur Rahman ${ }^{44}$ was published. He argues that Islamic education has been obstructing progress in all aspects of life? He translated the word "obstructing" as anti-reality education. In this context, the idea of sufistic Islamic education, including Mulkhan's MaQ, is not realistic and therefore is not able to offer any solutions for solving social problems. Any educational system that falls to solve humanistic problems is useless. By contrast, what Sutrisno calls on "invigorating" Islamic education is a system that offers solutions to problems faced by human beings. ${ }^{45}$

43 Sutrisno, Fąlur Rahman: Kajian terhadap Metode Epistemologi dan Sistem Pendidikan (Yogyakarta: Pustaka Pelajar, 2006).

44 Sutrisno, Pendidikan Islam yang Menghidupkan (Studi Kritis Terhadap Pemikiran Pendidikan Fazlur Rahman) (Yogyakarta: Kota Kembang, 2006).

45 Ibid. 
Rahman, for example, consistently offers alternative solutions for social problems. He describes four components necessary for the revival of Islamic education.

"Firstly, the purpose of education is to improve the quality of human (being) so that the lesson learnt will be embedded within individual life and create a critical, analytical, creative personality which further manages natural resources wisely for the sake of social justice and community advantages. Secondly, the enlightening educational materials involve natural science, history, and humanity. Thirdly, the appropriate teachinglearning method should incorporate inquiry, comprehensive, and analytical learning (dynamic) instead of repetitive memorization (mechanic). Fourthly, the evaluation should be directed to achieve the influential innovation contributing to answering the problems of humanity." ${ }^{46}$

The idea of "invigorating” Islamic education in Sutrisno's work Pendidikan Islam Berbasis Problem Sosialt7 asserts that Islamic education should emerge from social problems and then structured to solve those problems. This type of education will only be achieved if the concept of dualism in education is disregarded, replaced by a model that integrates the sciences with Islam.

In 2008, Sumedi wrote a dissertation on "Kritisisme Hikmah ke Arah Epistimologi Pendidikan Islam Humanis, Sintesis Epistimologi Barat dan Islam"48 but did not respond Mulkhan's recommendation to study Rahman's concept of ma'rifah, nor to continue Sutrisno's studies on Iqbal's and Rahman's thoughts. It put forward a comparison between Ibn Taymiyyah (Islamic philosophy) and Karl Raimund Popper (Western philosophy). Adopted Western science, Sutrisno and Mulkhan both created models that are compatible with Islamic education.

Also in 2008, Mahmud Arif wrote a dissertation on Pendidikan Islam Transformatif, ${ }^{49}$ which is different from others. In that he criticizes conceptual studies which are strongly reliant on the works of former

46 Ibid.

47 Sutrisno and Muhyidin Albarobis, Pendidikan Islam Berbasis Problem Sosial (Yogyakarta: Ar-Ruzz Media, 2012).

48 Sumedi, Kritisisme Hikmah ke Arah Epistemologi Pendidikan Islam Humanis: Sintesis Epistemologi Barat dan Islam (Yogyakarta: Bidang akademik UIN Sunan Kalijaga, 2008).

49 Mahmud Arif, Pendidikan Islam Transformatif (Yogyakarta: LKiS, 2008). 
Muslim scholars who are claimed to have religious authority and who reject changes to their views. According to Arif, this leads to a dull reproduction of former Muslim scholars' creativity added to apologetic theory. Arif's work seemed to split over the scientific map of FITK, i.e., the theocentric perspective which is represented by studies of former Muslim scholars, and the anthropocentric perspective, which is exemplified by empirical studies. It can be argued that FITK's scientific foundation should characterize the theo-anthropocentric perspective as proposed by Kuntowijoyo, and thus Islamic education will not be either secular or obstructive and anti-reality.

Although his work was not accepted by members of FITK, Mulkhan consistently, productively, and constructively contributed to the scientific foundation of FITK. In 2010, he wrote an article entitled "Tarbiyah Sebagai Ilmu dan Dasar Keilmuan Pendidikan Islam", 50 criticizing Islamic education science which he perceives as inconsistent and vague. The science foundation of Islamic education tends to adopt general sciences which have been considered secular. ${ }^{51}$ Mulkhan again recommends that FITK take into account Fazlur Rahman's and Harun Nasution's thoughts on ma'rifah. He further asserts that there are two types of ma'rifah: hidayah (gifted, God's absolute rights) and ikhtiari (human's attempts and creativity). ${ }^{52}$ Our capacity for creativity needs to be used in developing FITK as its philosophical foundation.

In 2012, eight years after the first publication of his idea on ma'rifah quotient (MaQ), Mulkhan published Rekonstruksi Filsafat Tarbiyab. ${ }^{53}$ Rejecting Jawad Ridha's research, he claims that "Islamic education science and theories have not yet been created." Mulkhan radically proclaims that science at FITK absolutely does not exist. Even if there are a number of publications on Islamic education philosophy or Islamic education science, those publications do not relate to philosophy or science. Rather, they are elaborations on Islamic dogmas. Mulkhan states that the absence

50 Mulkhan, "Tarbiyah Sebagai Ilmu dan Dasar Keilmuan Pendidikan Islam”.

51 Ibid.

52 Ibid.

53 Abdul Munir Mulkhan, Rekonstruksi Filsafat Tarbiyah: Dasar Pengembangan IImu \& Teknologi Pendidikan Islam, Laporan Penelitian (Yogyakarta: Fakultas Tarbiyah dan Keguruan, UIN Sunan Kalijaga, 2012). 
of Islamic education science has been the result of the failure to develop a comprehensive Islamic education philosophy (philosophy of Tarbiyah) which further results in the failure to construct Tarbiyah science and theories, as well as technology. Mulkhan adds:

"The philosophy of Islamic education or Tarbiyah philosophy should theoretically be structured under Islamic philosophy. In fact, Islamic education science or Tarbiyah science-if it exists-is structured and stems from neither the philosophy of Tarbiyah nor the philosophy of Islamic education. It can be seen from various books on Islamic education science which are arranged from neither the philosophy of Tarbiyah nor the philosophy of Islamic education... it should be admitted that, in practice, Islamic education is derived from sciences or theories which have been considered secular, non-Islamic, originated from Western conceptions and thoughts unconsciously built upon Islamic awareness. ${ }^{54}$

It can be assumed that when Mulkhan used the term "secular" he employed only possible one perspective. According to Sutrisno, however, general science cannot be absolutely judged as secular because historically the cultural transition from the Muslim world to the West in the $13^{\text {th }}$ century, included the sciences so learning Western science is to some extent also to learning Islam. Mulkhan's ideas could be evaluated and compared to those of Ahmad Tafsir, who rejected the terminology of "pendidikan Islam" and further proposed the employment of the term "pendidikan Islami” meaning education which characterizes Islam. Tafsir asserts that "pendidikan Islam?" is general education harmonious with Islamic values. Meanwhile Rena Dossett's study aggrees with Sutrisno's argument that Western humanistic education stems from the Middle Ages of Islam also called "scholastic Islam". ${ }^{55}$ Therefore, the philosophical foundations of Islamic education, Islamic education science, Islamic education theory, and Islamic education technology are not secular sciences labeled "Islam". All of these general sciences should be accompanied by and even embedded in Islamic values.

In 2013, Mulkhan reintroduced ma'rifah quotients (MaQ) which

${ }^{54}$ Ibid.

55 Rena D. Dossett, "The Historical Influence of Classical Islam on Western Humanistic Education", International Journal of Social Science and Humanity, vol. 4, no. 2 (2014), pp. 2-5. 
initially came up in 2004 as the philosophical foundation for FITK. In an article published in 2013 in the Jurnal Pendidikan Islam entitled "Filsafat Tarbiyah Berbasis Kecerdasan Ma'rifat." ${ }^{\prime 56}$ Mulkhan summarized MaQ as:

"Ma'rifah quotient $(\mathrm{MaQ})$ is a function of intellectual intuition as the ultimate synthesis of soul, energy, and physical reality. A human is an integrated individual with an intellectual competence, namely intuition as the final synthesis. Through this intuition (kasyf), playing as a continuous evolution of intellectuality, a human being is able to comprehend the entire form of reality as the basis of affective conscience about the synthetic unity of the structure and the social responsibility". ${ }^{57}$

In brief, Mulkhan's summary of the reconstruction of the philosophy of Tarbiyah has reached an operational definition of the underlying philosophy of Tarbiyah, namely MaQ. MaQ is the initial step for the development of the philosophy of Tarbiyah. Moreover, considering Thomas Kuhn's theory of revolution of paradigm for knowledge, MaQ is unlikely to be categorized as the basis of Islamic education philosophy because it has not addressed the components of a scientific structure. Nonetheless, as the initial stage, Mulkhan's struggle for a paradigm for science should be respected, not as a museum of a conceptual framework for science. Rather, it should be considered as a foundation for a laboratory of thoughts.

Even since the 1990s, Mulkhan and Sutrisno have been FITK lecturers who have consistently, constructively, and productively, produced influential works to establish and develop a FITK scientific foundation. However, most of other FITK lecturers' works stopped with their dissertations, which are usually published as books or journal articles. Mahmud Arif's examination of these scholars devided them into two different ways to characterize science: Mulkhan's theocentric-sufism and Sutrisno's dialectic-theo-anthropocentric. This distinction has led to the second phase of the dynamic of science at FITK, which is called the dichotomy of sufism-Islamic education.

\section{Dialectic-Integrative Aspects Of Islamic Education}

The dialectics of Islamic education are defined as the study of

\footnotetext{
56 Mulkhan, "Filsafat Tarbiyah Berbasis Kecerdasan Makrifat".

${ }^{57}$ Ibid.
} 
Islamic education aimed at exploring and analyzing particular concepts in the field of Islamic education and then comparing them with concepts in other disciplines. However, the term "integration" is better than "dialogue" because the goal is the unification of all disciplines as parts of Islamic scientific education..$^{58}$ The purpose of having dialectics in Islamic education is to give a clear futuristic direction for a scientific foundation at FTIK which is actually prepared to support the paradigm of integration-interconnection. However, it has not yet provided a comprehensive concept of its structure. In other words, although a number of studies at FITK have adopted this paradigm, they have not yet offered a formulation of comprehensive thoughts, such as the study on psychology and language (psycholinguistics) or that of anthropology and language in combination (anthropolinguistic). Amin Abdullah acknowledges that religious education even now prefers the paradigm of conflict and independence to what Barbour proposed as the paradigm of integration-interconnection. Structurally, the issue of integrative science in Islamic studies was led by Amin Abdullah (Rector of UIN Sunan Kalijaga 2001-2005 \& 2005-2010)..$^{59}$ Dean of FITK (2007-2011), Sutrisno, agreed so integration-interconnection became the structural and political policy within the university. Since that time, many lectures at FITK have used the approach for conducting research. In supporting this, Assegaf states that because FITK receives many new lecturers from Western universities, this will bring a change in the way they teach, including using multidisciplinary approaches. They would also shift from the normative approach to the historical-integral approaches. ${ }^{60}$ Until now, the scientific-dynamic aspects of the curriculum remain dialectical instead of integrative. ${ }^{61}$ In summary, the lecturers at FITK have used the

58 Ian G. Barbour, Juru Bicara Tuhan: Antara Sains dan Agama, trans. by E.R. Muhammad (Bandung: Mizan, 2002).

59 M. Amin Abdullah, Transformasi LAIN Sunan Kalijaga menjadi UIN Sunan Kalijaga, Laporan pertanggungjawaban Rektor UIN Sunan Kalijaga periode 2006-2010 (Yogyakarta: UIN Sunan Kalijaga, 2010).

${ }^{60}$ Assegaf, Zakaria, and Sulaiman, "The Closer Bridge towards Islamic Studies in Higher Education in Malaysia and Indonesia".

61 M. Amin Abdullah, "Religion, Science, and Culture: An Integrated, Interconnected Paradigm of Science", Al-Jami'ah: Journal of Islamic Studies, vol. 52, no. 1 (2014), p. 175. 
dialectic approach — not the integrative one-so that they are not able to develop and introduce integrative concepts. ${ }^{62}$

Although Amin Abdullah is the central figure and pioneer of Islamic integrative science, the issue is also important Belgium and other countries. Patrick Loobuyck and Leni Franken studied integrative religion and Islamic education in Belgium ${ }^{63}$ and the research of Nik Ahmad Hisham İsmail and Mustafa Tekke on attitudes in integrative Islamic and Western perspectives ${ }^{64}$ have strongly indicated greater issues in integrative science worldwide. $^{65}$

Amin Abdullah differenciates between the concept of integration and interdisciplinary study. ${ }^{66}$ The former refers to research using varied disciplines that unify in one person, while the later is an object of research conducted by many people. Ian G. Babour who studied physics, theology, and philosophy ${ }^{67}$ and Martin van Bruinessen, who also studied mathmetics, physics, anthropology, and sociology, may represent what is meant by Abdullah. ${ }^{68}$ Martin puts, "I had studied mathematics and theoretical physics and had worked as a mathematics teacher, and I had also studied some anthropology on the side and later made that my main occupation when I found a grant to do fieldwork....

Abd Rachman Assegaf is the second lecturer, following Sutrisno,

${ }^{62}$ Barbour, Juru Bicara Tuhan: Antara Sains dan Agama, p. 74.

63 Patrick Loobuyck and Leni Franken, "Towards Integrative Religious Education in Belgium and Flanders: Challenges and Opportunities", British Journal of Religious Education, vol. 33, no. 1 (2011), pp. 17-30.

${ }^{64}$ Mustafa Tekke and Nik Ahmad Hisham Ismail, "Development and Initial Validation of Integrative Islamic Personality Inventory", Advances in Environmental Biology, vol. 9, no. 18 (2015).

65 Abdullah, "Religion, Science, and Culture".

66 M. Amin Abdullah, "Multidisiplin, Interdisiplin, dan Transdisiplin", in Era Dismpsi: Peluang dan Tantangan Pendidikan Tinggi Indonesia, ed. by Daniel Dhakidae (Jakarta: Akademi Ilmu Pengetahuan Indonesia, 2017).

${ }^{67}$ Ian G. Barbour, Issues in Science and Religion (Englewood Cliffs, N.J: PrenticeHall, 1966).

68 Waston, "Hubungan Sains dan Agama: Refleksi Filosofis atas Pemikiran Ian G. Barbour”, Profetika: Jurnal Studi Islam, vol. 15, no. 1 (2016), pp. 76-89.

69 Martin van Bruinessen, "In the Tradition or Outside? Reflections on Teachers and Influences”, Al-jami'ab: Journal of Islamic Studies, vol. 53, no. 1 (2015), p. 53. 
conducting research by employing the paradigm of integrationinterconnection. In 2007, he wrote a book entitled Desain Riset SosialKeagamaan, Pendekatan Integratif-Interkonektif..$^{70}$ None of its twelve chapters discusses the paradigm of integration-interconnection in social-religious research. In Chapter Three, he examines inductive and deductive reasoning, but he ignores abductive reasoning as the entry point into the paradigm of the integration-interconnection. His approach to research, whether sociological, psychological, naturalistic, historic, or experimental, does not mention the integrative-interconnective approach. The book seems to move backward three years before Amin Abdullah wrote "Metodologi Penelitian untuk Pengembangan Studi Islam, Perspektif Delapan Point Sudut Pandang." ${ }^{\text {"11 }}$ Abdullah's article was presented at the Workshop Metodologi Penelitian for FITK's lecturers in 2004. Abdullah states that an important step in research following the concept of integrationinterconnection is to implement the intertwined eight perspectives. In 2005, the article was published in Jurnal Religi, and subsequently, in 2006, it appeared in the anthology Metodologi Penelitian Agama: Pendekatan Multidisipliner. ${ }^{72}$ Waryani Fajar Riyanto developes Abdullah's article into circulation, abductification, hermeneutization ${ }^{73}$ to implement the approach of integration-interconnection in research methodology. In the meantime, Assegaf's work on research designs still lags behind this dynamics new paradigm.

Five years later, in 2011, Assegaf published Filsafat Pendidikan Islam: Paradigma Baru Pendidikan Hadhari Berbasis Integratif-Interkonektif $f^{74}$ the results for his postdoctoral advanced research written in 2007-2008

70 Abd Rachman; Assegaf, Desain Riset Sosial-Keagamaan: Pendekatan Integratifinterkonektif (Yogyakarta: Gama Media \& CDIE UIN Sunan Kalijaga, 2007).

71 M. Amin Abdullah, "Metodologi Penelitian untuk Pengembangan Studi Islam, Perspektif Delapan Point Sudut Pandang”, Religi: Jurnal Studi Agama-Agama, vol. 4, no. 1 (2005), pp. 16-37.

72 Abdullah, "Metodologi Penelitian untuk Pengembangan Studi Islam, Perspektif Delapan Point Sudut Pandang".

73 Waryani Fajar Riyanto and Mardjoko Idris, Implementasi Paradigma IntegrasiInterkoneksi dalam Penelitian 3 (tiga) Disertasi Dosen UIN Sunan Kalijaga (Yogyakarta: Lemlit UIN Sunan Kalijaga, 2012).

74 Abd Rachman Assegaf; Filsafat Pendidikan Islam: Paradigma Baru Pendidikan Hadhari Berbasis Integratif Interkonektif (Jakarta: Raja Grafindo Persada, 2011). 
in Malaysia and sponsored by Sunan Kalijaga State Islamic University. Assegaf applies four pillars to the educational concept of hadhari: the oneness of God, virtuous morality (akblaq), theory of natural tendency (fitrab), and masjid empowerment as the center of ummah development. One pillar links to the other and subsequently forms "chambers of cultures", i.e., scriptural culture (hadharah an-nash), scientific culture (hadharah al-ilm) and philosophical culture (hadharah al-falsafah). Amin Abdullah in a preface describes his project:

"I perceive that Abd Rachman Assegaf, professor of Islamic education in the Faculty of Tarbiyah dan Keguruan Sunan Kalijaga State Islamic University, has made a great attempt to explain the concept of Islamic education based on the scientific paradigm of integration-interconnection. It can be clearly seen from the discussion in this book which is arranged appropriately into three cultural entities (hadharah). The implementation of each hadharab in Islamic education is explained comprehensively". 75

Waryani Fajar Riyanto, however, criticizes Assegaf's work and compares it to an analogy as it is an unlit torch. If the three hadharahs proposed by Hadhari are comparable to a torch with three hadharah as its batteries, then the four pillars suggested by Assegaf may be considered merely additional components which are not yet capable of enlightening the darkness of scientific atomism. For example, in terms of empowering the worship place such as masjid as the center of empowering ummah, Amin Abdullah has established the masjid on the campus UIN Sunan Kalijaga not only as a place for developing ummah, but also as elaboration of religion, and furthermore, it becomes the symbol of modernity, locality, and Islam. ${ }^{76}$ To this point, Assegaf's works on Islamic education and the paradigm of integration-interconnection essentially remain dialectical, not yet integrative in nature.

Likewise, in 2012, Maksudin, another FITK lecturer, also contributed to the discussion on the paradigm of integration-interconnection in his book Pendidikan Karakter Non Dikotomik which was then published in

${ }^{75}$ M. Amin Abdullah, "Tiga Lapis Wilayah Keilmuan Pendidikan Islam Integratif-Interkonektif”, in Filsafat Pendidikan Islam: Paradigma Baru Pendidikan Hadhari Berbasis Integratif Interkonektif (Jakarta: Raja Grafindo Persada, 2011), pp. vi-x.

76 Waryani Fajar Riyanto, Integrasi-Interkoneksi Keilmuan: Biografi Intelektual M. Amin Abdullab (1953-...) Person, Knowledge, and Institution (Yogyakarta: Suka Press, 2013). 
Jurnal Pendidikan Karakter. In 2013 and 2015, he also wrote two books Paradigma Agama dan Sains Nondikotomik and Desain Pengembangan Berpikir Integratif-Interkonektif Pendekatan Dialektik. ${ }^{77}$ At the same time, Sutrisno also published his latest book Pendidikan Islam di Era Peradaban Modern. ${ }^{78}$

Maksudin's works indeed suggest a progressive response to the paradigm of integration-interconnection. However, the content still involves dialectical reasoning. Moreover, the approaches applied are still subjective (Islam) disregarding science-intersubjectivity. This can be seen from his book Agama dan Sains Nondikotomik in which Maksudin employes dichotomous reasoning or non-dichotomy without studying the development of human characters through history-archeology as perceived by Foucault: "...The character should be composed of the most careful description of the fructification? of the first species. All the other species of the genus are compared with the first, all discordant notes being eliminated; finally, after this process, the character emerges." ${ }^{79}$ In that book also, Maksudin began by describing Allah, then the Prophet Muhammad, and subsequently alQur'an and al-Hadis, followed by the next, down to the three hadharabs (hadharah al-nash, hadharah al-falsafah, dan hadharah al-ilm), and ending with qauliyah and qauniyah. ${ }^{80}$ Meanwhile, although Sutrisno has not employed the integrative approach, he has begun to apply the interconnection approach. For instance, in Chapter Two of his latest book, he discussed "Interkoneksitas Sistem Pendidikan Sains dan Agama untuk Membangun Mutu Pendidikan Bangsa". ${ }^{81}$

In order to make the dynamics of FITK science abistorical?, many concepts have emerged along the historical phases. Their threds could be used as a new solid conceptual framework about Islamic education science. The threads would have to be systematically defined in a way that

77 Maksudin, Desain Pengembangan Berpikir Integratif Interkonektif Pendekatan Dialektif (Yogyakarta: Pustaka Pelajar, 2015).

78 Sutrisno and Suyatno, Pendidikan Islam di Era Peradaban Modern (Jakarta: Prenada Media, 2015).

79 Michel Foucault, The Order of Things: An Archaeology of the Human Sciences (New York: Routledge Classic, 2002). Dialektif.

${ }^{80}$ Maksudin, Desain Pengembangan Berpikir Integratif Interkonektif Pendekatan

81 Sutrisno, Pendidikan Islam yang Menghidupkan (Studi Kritis Terbadap Pemikiran Pendidikan Fąlur Rabman). 
shows that they can be integrated. This integration could possess five circles: 1) (al-Qur'an and Sunnah as central; 20 appraches and methods; 3) religious teachings; 4) science, and 50 global issues. Integrative Islamic education science would then start from Muhammad Anis' integrative tafsir tarbawi. From there it would go to 1) research methodology of integrative Islamic education; 2) then phylosophy of integrative Islamic education; 3) then curricula of integrative Islamic education, and finally to 4) global issues in contemporary education.

The verses of integrative Tafsir Tarbawi proposed by Muhammad Anis could be the philosophical basis of the integrative Islamic education. It can then be connected to al-Qur'an and Sunnah which would constitute the core of the integrative-interconnective paradigm. However, the interpretation may require adopting Amin Abdullah's idea of ta'wil alilm. Previously, "ta'wil zabiriyah" has been attached to al-Jabiri's science Islamization, while "ta'wil batiniyah" was devoted to Kuntowijoyo's Islam scientification (considering Islam as science). Amin Abdullah's ta'wil al-ilm will actually enrich Muhammad Anis' tafsir tarbawi into integrative tafsir tarbawi.

The philosophy of integrative education that could be explicated from the concept of hadhari in Assegaf's philosophy of Islamic education should be the philosophic foundation for Islamic integrative education in all disciplines. However, the concept still needs to adopt Islamic and Western philosophy of criticism as proposed by Sumedi. It also must include Mulkhan's recommedation to incorporate Islamic philosophy. The philosopy of Islamic education therefore does not refer only to a monodiscipline but also to multidisciplines, and one of them is Western philosophy. The ma'rifah quotient $(\mathrm{MaQ})$ proposed by Mulkhan as the basic philosophy of integrative Islamic education is insufficient because it is dichotomous in nature. Nonetheless, $\mathrm{MaQ}$ can be placed within integrative Islamic educational psychology, equal to IQ, EQ, and SQ. Thus, there will be a continuous hierarchy form IQ, EQ, SQ, to MaQ.

The research methodology of integrative Islamic education could be modified. Assegaf's research design needs further modification to fit the eight points of Amin Abdullah's view and fit with the method of circulation, abductivication, and hermenutics (SAH) as offered by Waryani Fajar Riyanto. Riyantyo's method is designed to appreciate experimental 
observation, rational-demontrative, reasoning insight and intuitive. It also could meet the challenge proposed by Mulkhan that Islamic education needs to respond to metaphysical concepts. Studies need to be integrated with metaphysics. This method could also bridge the conflict between Mulkhan's MaQ and Arif's transformative education.

Sutrisno's thoughts could contribute to enhhancing the integrative curricula of Islamic education, particularly his ideas on creativity that stem from Muhammad Iqbal and Fazlur Rahman. Sutrisno insists that the curricula of Islamic education cover objectives, contents, methods, and evaluation. In this context, the contents may include natural science, history, social science, and others. Thereofore, Islamic education needs to provide the foundation to bind all disciplines into one model of "integrative-interconnective" education. Contemporary issues in integrative Islamic education may also cover a discourse that combines diverse disciplines, such as biology and ethics (bioethics), theology and neuroscience (neurotheology), anthropology and Islamic education, psychology and Islamic education, and others. Therefore, students will learn a variety of science at FITK.

\section{E. Concluding Remarks}

The archeological roots of integrative Islamic education can best be described by Foucault's archeology of knowledge. Using Foucault's terms when FITK was established in 1951. It adopted the normative-idealist approach to Islamic education science. This was probably because many of the lecturers studied in the Middle East universities. The translation activities and resources used were based on this approach. Some examples are 1) Tarbiyatul Aulad fil Islam by Abdullah Nashekh Ulwan; 2) Sejarah Pendidikan Islam that was translated by Muchtar Yahya from its original version Tarikh at-Tarbiyyah al-Islamiyah; and 3) Syamsuddin's Sistem Pendidikan Versi al-Ghazali translated from al-Mazhab al-Tarbawi inda al-Ghazali. Today, Islam has a global impact. Islamic teachings are educational models need to be modified as to fit with current trends in the sciences and social sciences. Later, scholars in Turkey modernized Islamic education science.

Future research needs to trace the genealogycal roots of integrative science. Rigorous research needs to be done on whether the integration of 
science and Islam is possible and beneficial. The philosopy of integrative Islamic education should begin with the hadhari philosophy of Islamic education and then enriched with criticism. The methodology of research in Islamic education should be integrative following Assegaf's design. It also needs to cover the eight points of Amin Abdullah's suggestion and the SAH proposed by Waryani Fajar Riyanto. The core of the FITK science should adopt the ma'rifah quotient $(\mathrm{MaQ})$ suggested by Mulkhan to develop creativity and criticism (Muhammad Iqbal and Fazlur Rahman). Together, scholars today can develop an enlightening Islamic education as initiated by Sutrinso. 
A Genealogycal Study of Islamic Education the Science

\section{BIBLIOGRAPHY}

Abdullah, M. Amin, "Metodologi Penelitian untuk Pengembangan Studi Islam, Perspektif Delapan Point Sudut Pandang", Religi: Jurnal Studi Agama-Agama, vol. 4, no. 1, 2005.

----, Transformasi IAIN Sunan Kalijaga menjadi UIN Sunan Kalijaga, Laporan pertanggungjawaban Rektor UIN Sunan Kalijaga periode 2006-2010, Yogyakarta: UIN Sunan Kalijaga, 2010.

----, "Tiga Lapis Wilayah Keilmuan Pendidikan Islam IntegratifInterkonektif", in Filsafat Pendidikan Islam: Paradigma Baru Pendidikan Hadhari Berbasis Integratif Interkonektif, Jakarta: Raja Grafindo Persada, 2011.

----, "Religion, Science, and Culture: An Integrated, Interconnected Paradigm of Science", Al-Jami'ab: Journal of Islamic Studies, vol. 52, no. 1, 2014, pp. 175-203 [http://dx.doi.org/10.14421/ ajis.2014.521.175-203].

----, "Multidisiplin, Interdisiplin, dan Transdisiplin", in Era Disrupsi: Peluang dan Tantangan Pendidikan Tinggi Indonesia, ed. by Daniel Dhakidae, Jakarta: Akademi Ilmu Pengetahuan Indonesia, 2017.

Anis, Muh, Tafsir Ayat - Ayat Pendidikan, Yogyakarta: Mentari Pustaka, 2010.

Arif, Mahmud, Pendidikan Islam Transformatif, Yogyakarta: LKiS, 2008.

Assegaf, Abd Rachman, Desain Riset Sosial-Keagamaan: Pendekatan IntegratifInterkonektif, Yogyakarta: Gama Media \& CDIE UIN Sunan Kalijaga, 2007.

----, Filsafat Pendidikan Islam: Paradigma Baru Pendidikan Hadhari Berbasis Integratif Interkonektif, Jakarta: Raja Grafindo Persada, 2011.

Assegaf, Abd Rachman, Abd Razak Bin Zakaria, and Abdul Muhsein Sulaiman, "The Closer Bridge towards Islamic Studies in Higher Education in Malaysia and Indonesia", Creative Education, vol. 3, no. 6A, 2012, p. 986 [http://dx.doi.org/10.4236/ce.2012.326149].

Azra, Azyumardi, Jejak-Jejak Jaringan Kaum Muslim: Dari Australia bingga Timur Tengah, Bandung: Hikmah, 2007.

Balci, Bayram, "Between Secular Education and Islamic Philosophy: The 
Approach and Achievements of Fethullah Gülen's Followers in Azerbaijan":, Caucasus Survey, vol. 1, no. 1, 2013, pp. 107-16 [http:// dx.doi.org/https://doi.org/10.1080/23761199.2013.11417275].

Barbour, Ian G., Issues in Science and Religion, Englewood Cliffs, N.J: Prentice-Hall, 1966.

----, Juru Bicara Tuhan: Antara Sains dan Agama, trans. by E.R. Muhammad, Bandung: Mizan, 2002.

Bruinessen, Martin van, "In the Tradition or Outside? Reflections on Teachers and Influences", Al-Jami'ab: Journal of Islamic Studies, vol. 53, no. 1, 2015, pp. 53-103 [http://dx.doi.org/10.14421/ ajis.2015.531.53-103].

Dossett, Rena D., "The Historical Influence of Classical Islam on Western Humanistic Education", International Journal of Social Science and Humanity, vol. 4, no. 2, 2014, pp. 88-91 [http://dx.doi.org/10.7763/ IJSSH.2014.V4.324].

Foucault, Michel, "The Archaeology of Knowledge":, Social Science Information, vol. 9, no. 1, 1970, pp. 175-85 [http://dx.doi.org/10.1 177/053901847000900108].

----, "The Politics of Health in the Eighteenth Century", in Power/ Knowledge: Selected Interviews and Other Writings, 1972-1977, ed. by Colin Gordon, New York: Harvester Wheatsheaf, 1980.

----, The Order of Things: An Archaeology of the Human Sciences, New York: Routledge Classic, 2002.

Garland, David, "What is a 'History of the Present'? On Foucault's Genealogies and Their Critical Preconditions", Punishment \& Society, vol. 16, no. 4, 2014, pp. 365-84 [http://dx.doi. org/10.1177/1462474514541711].

Goleman, Daniel, Kecerdasan Emosional, trans. by T. Hermaya, Jakarta: Gramedia Pustaka Utama, 2006.

Karwadi, "Emotional Quotient in Islamic Educational Perspective: A Study on Elements of Emotional Quotient Hasan Langgulung's Perspective", Ph.D. Dissertation, Yogyakarta: Sunan Kalijaga State Islamic University, 2008.

Knott, Kim, "Insider/Outsider Perspectives", in The Routledge Companion to 
the Study of Religion, ed. by John R. Hinnells, London: Routledge, 2005. Loobuyck, Patrick and Leni Franken, "Towards Integrative Religious Education in Belgium and Flanders: Challenges and Opportunities", British Journal of Religious Education, vol. 33, no. 1, 2011, pp. 17-30 [http://dx.doi.org/10.1080/01416200.2011.523517].

Machali, Imam (ed.), Pendidikan Islam dan Tantangan Globalisasi, Yogyakarta: Presma dan Ar-Ruzz Media, 2004.

Maksudin, Pendidikan Karakter Non-Dikotomik, Yogyakarta: Pustaka Pelajar, 2012.

----, "Pendidikan Karakter Nondikotomik: (Upaya Membangun Bangsa Indonesia Seutuhnya)", Jurnal Pendidikan Karakter, vol. 3, no. 2, 2013 [http://dx.doi.org/http://dx.doi.org/10.21831/jpk.v2i2.1435].

----, Desain Pengembangan Berpikir Integratif Interkonektif Pendekatan Dialektif, Yogyakarta: Pustaka Pelajar, 2015.

Mulkhan, Abdul Munir, "Kesalahen Multikultural dalam Pendidikan Islam", in Pendidikan Islam dan Tantangan Globalisasi, ed. by Imam Machali, Yogyakarta: Presma dan Ar-Ruzz Media, 2004.

----, "Kecerdasan Ma'rifat dan Revolusi Spiritual dalam Tradisi Sufi", Jurnal Pendidikan Islam, vol. 2, no. 1, 2004.

----, "Tarbiyah Sebagai Ilmu dan Dasar Keilmuan Pendidikan Islam”, in Antologi Kependidikan Islam, Yogyakarta: Jurusan Kependidikan Islam Fakultas Tarbiyah dan Keguruan UIN Sunan Kalijaga, 2010, pp. 219-39.

----, Rekonstruksi Filsafat Tarbiyah: Dasar Pengembangan IImu \& Teknologi Pendidikan Islam, Laporan Penelitian, Yogyakarta: Fakultas Tarbiyah dan Keguruan, UIN Sunan Kalijaga, 2012.

----, "Filsafat Tarbiyah Berbasis Kecerdasan Makrifat", Jurnal Pendidikan Islam, vol. 2, no. 2, 2013, pp. 219-39 [http://dx.doi.org/10.14421/ jpi.2013.22.219-239].

Munhanif, Ali, "Prof. Dr. A. Mukti Ali: Modernisasi Politik-Keagamaan Orde Baru", in Menteri-Menteri Agama RI: Biografi Sosial-Politik, ed. by Saiful Umam and Azyumardi Azra, Jakarta: Diterbitkan atas kerjasama Indonesian-Netherlands Cooperation in Islamic Studies (INIS), Pusat Pengkajian Islam dan Masarakat (PPIM), Badan 
Litbang Agama, Depertemen Agama RI, 1998.

Nasution, Khoiruddin, Ahmad Pattiroy, and Slamet Khilmi (eds.), Dari Hasbi Ash-Shiddieqy hingga Malik Madany: Pemikiran Hukum Islam Dekan Fakultas Syari'ah UIN Sunan Kalijaga Yogyakarta, 1963-2007, Yogyakarta: Fakultas Syari'ah Press, 2009.

Nurwadjah, Ahmad E. Q; Tafsir Ayat-Ayat Pendidikan: Hati yang Selamat bingga Kisah Luqman, Bandung: Marja, 2007.

Nuryatno, M. Agus, "Comparing Religious Education in Indonesia and Japan”, Al-Jami'ab: Journal of Islamic Studies, vol. 52, no. 2, 2014, pp. 435-58 [http://dx.doi.org/10.14421/ajis.2014.522.435-458].

Osella, Filippo and Benjamin Soares (eds.), Islam, Politics, Anthropology, Malden, Massachusetts: Wiley-Blackwell, 2010.

Raihani, "Minority Right to Attend Religious Education in Indonesia", Al-Jami'ah: Journal of Islamic Studies, vol. 53, no. 1, 2015, pp. 1-26 [http://dx.doi.org/10.14421/ajis.2015.531.1-26].

----, "Delivering Islamic Studies and Teaching Diversity in Southern Thai Islamic Schools", Al-jami'ah: Journal of Islamic Studies, vol. 54, no. 1, 2016, pp. 123-46 [http://dx.doi.org/10.14421/ajis.2016.541.123146].

Riyanto; Waryani Fajar, Integrasi-Interkoneksi Keilmuan: Biografi Intelektual M. Amin Abdullah (1953-...) Person, Knowledge, and Institution, Yogyakarta: Suka Press, 2013.

Riyanto, Waryani Fajar and Mardjoko Idris, Implementasiparadigma integrasiinterkoneksi dalam penelitian 3 (tiga) disertasi dosen UIN Sunan Kalijaga, Yogyakarta: Lemlit UIN Sunan Kalijaga, 2012.

Salleh, Muhammad Syukri, “Strategizing Islamic Education”, International Journal of Education and Research, vol. 1, no. 6, 2013.

Springer, Simon, "Neoliberalism as Discourse: between Foucauldian Political Economy and Marxian Poststructuralism", Critical Discourse Studies, vol. 9, no. 2, 2012, pp. 133-47 [http://dx.doi.org/10.1080/ 17405904.2012.656375].

Sumedi, Kritisisme Hikmah ke Arah Epistemologi Pendidikan Islam Humanis: Sintesis Epistemologi Barat dan Islam, Yogyakarta: Bidang akademik UIN Sunan Kalijaga, 2008. 
Suryadilaga, M. Alfatih and Fachruddin Faiz, Profil LAIN Sunan Kalijaga Yogyakarta 1951-2004, Yogyakarta: Suka Press, 2004.

Sutrisno, "Pengembangan Kreatifitas dalam Pendidikan Islam Kontemporer, Telaah Atas Pemikiran Muhammad Iqbal", in Pendidikan Islam dalam Konsepsi dan Realitas, ed. by Abd. Rachman Assegaf, Yogyakarta: Lembaga Penelitian UIN Sunan Kalijaga, 2006.

----, Fąlur Rahman: Kajian terbadap Metode Epistemologi dan Sistem Pendidikan, Yogyakarta: Pustaka Pelajar, 2006.

----, Pendidikan Islam yang Mengbidupkan (Studi Kritis Terbadap Pemikiran Pendidikan Fąlur Rahman), Yogyakarta: Kota Kembang, 2006.

----, "Mengingat Kembali Jiwa Pendidikan Sebagai Respon Terhadap Globalisasi", in Antologi Pendidikan Islam, ed. by Nizar Ali and Sumedi, Yogyakarta: Program Studi Pendidikan Islam Program Pascasarjana UIN Sunan Kalijaga dan Idea Press, 2010.

----, "Integrating Science and Islam: A Case Study of State Islamic University (UIN) Sunan Kalijaga, Yogyakarta, Indonesia", in Critical Issues and Reform in Muslim Higher Education, ed. by Rosnani Hashim and Mina Hattori, Kuala Lumpur: IIUM Press, 2015.

Sutrisno and Muhyidin Albarobis, Pendidikan Islam Berbasis Problem Sosial, Yogyakarta: Ar-Ruzz Media, 2012.

Sutrisno and Suyatno, Pendidikan Islam di Era Peradaban Modern, Jakarta: Prenada Media, 2015.

Tekke, Mustafa and Nik Ahmad Hisham Ismail, "Development and Initial Validation of Integrative Islamic Personality Inventory", Advances in Environmental Biology, vol. 9, no. 18, 2015.

Tim Penyusun, Kurikulum Fakultas Tarbiyah Institut Agama Islam Negeri (IAIN) Sunan Kalijaga, Yogyakarta: IAIN Sunan Kalijaga, 1970.

----, Silabus fakultas Tarbiyah LAIN, Jakarta: Proyek Pembinaan Perguruan Tinggi Agama Islam/IAIN di Pusat Direktorat Pembinaan Perguruan Tinggi Agama Islam, 1981.

Umar, Ahmad Rizky Mardhatillah, "A Genealogy of Moderate Islam: Governmentality and Discourses of Islam in Indonesia's Foreign Policy", Studia Islamika, vol. 23, no. 3, 2016, pp. 399-433 [http:// dx.doi.org/10.15408/sdi.v23i3.3157]. 
Waston, "Hubungan Sains dan Agama: Refleksi Filosofis atas Pemikiran Ian G. Barbour", Profetika: Jurnal Studi Islam, vol. 15, no. 1, 2016, pp. 76-89 [http://dx.doi.org/https://doi.org/10.23917/profetika. v15i1.1968].

Wekke, Ismail Suardi, "Arabic Teaching and Learning: A Model from Indonesian Muslim Minority", Procedia - Social and Behavioral Sciences, vol. 191, 2015, pp. 286-90 [http://dx.doi.org/10.1016/j. sbspro.2015.04.236].

Widiyanto, Asfa, “The Reception of Seyyed Hossein Nasr's Ideas within the Indonesian Intellectual Landscape", Studia Islamika, vol. 23, no. 2, 2016, pp. 193-236 [http://dx.doi.org/10.15408/sdi.v23i2.3002].

Zohar, Danah and Ian Marshall, SQ: Memanfaatkan Kecerdasan Spiritual Dalam Berpikir Integralistik dan Holistik untuk Memaknai Kebidupan, trans. by Rahmani Astuti, Ahmad Nadjib Burhani, and Ahmad Baiquni, Bandung: Mizan, 2001. 